\title{
Potensi Bakteri Filosfer Sebagai Agens Hayati Penyakit Pustul (Xanthomonas axonopodis Pv.Glycines) Dan Pemacu Pertumbuhan Kedelai
}

\author{
The Ability of Phyllosphere Bacteria as Biological Agent of Pustule Disease (Xanthomonas \\ axonopodis pv.glycines) and as Soybean Growth Promotion
}

\author{
Suhartiningsih Dwi Nurcahyani ${ }^{* 1}$, Wiwiek Sri Wahyuni ${ }^{2}$, Rachmi Masnillah ${ }^{3}$ \\ Program Studi Proteksi Tanaman, Fakultas Pertanian, Universitas Jembmer, Jember. \\ e-mail: ${ }^{* 1}$ suhartiningsih.faperta@unej.ac.id, ${ }^{2}$ wiwiekwahyuni@gmail.com, \\ 3rachmimasnillah@yahoo.com
}

\begin{abstract}
ABSTRAK
Penyakit pustul bakteri yang disebabkan oleh Xanthomonas aonopodis pv. Glycines (Xag) merupakan penyakit penting pada kedelai. Kami menggunakan 11 isolat bakteri filosfer JB 4, JB5, JB6, JB7, JB12, JB1, ST31, ST32, ST4, LB2 dan LB3 sebagai agen hayati karena mempunyai "niche" yang sama dengan pathogen, untuk mengetahui kemampuannya dalam mengendalikan Xag dan memacu pertumbuhan tanaman kedelai. Hasil in vitro menunjukkan bahwa inokulasi Xag pada benih kedelai akan menurunkan daya kecambah kedelai. Seed treatment dengan menggunakan bakteri filosfer mampu meningkatkan perkecambahan kedelai yang terinfeksi Xag. Isolat JB 5 dan JB 7 merupakan isolate terbaik dengan daya kecambah yang sama 95\% dengan efektivitas $\pm 35.71 \%$ dibandingkan kontrol. Sedangkan isolat JB13 terbaik dalam meningkatkan panjang radikula yaitu 3,13 cm dengan efektivitas 104,58\%. Isolat JB7, JB12, JB13 dan ST32 mempunyai kemampuan yang sama dalam mengendalikan penyakit pustule kedelai di rumah kaca dengan keparahan penyakit berkisar $\pm 21,37$ dan efektivitas $\pm 66.41 \%$. Isolat JB 12 dan JB13 menunjukkan kemampuan yang terbaik dalam meningkatkan tinggi tanaman yaitu $\pm 95.58 \mathrm{~cm}$, jumlah cabang \pm 5.53dan jumlah daun \pm 29.89. Isolate JB12, JB13 dan ST32, diikuti JB5 dan JB7 berpotensi sebagai agen hayati untuk mengendalikan penyakit pustul dan meningkatkan pertumbuhan kedelai.
\end{abstract}

Kata kunci : Bakteri filosfer, Kedelai, Xanthomonas axonopodis pv. Glycines

\section{ABSTRACT}

Bacterial pustule disease caused by Xanthomonas axonopodis pv. glycines (Xag) are important diseases in soybean. In this research, we use 11 phylosphere bacteria, $J B 4, J B 5, J B 6, J B 7, J B 12, J B 1$, ST31, ST32, ST4, LB2 and LB3 as biological agents which has the same "niche" with that of pathogen, to determine wether these bacteria either have ability to control Xag and stimulated soybean growth. In vitro assay showed that inoculation Xag on soybean seeds reduced soybean germination. Seed treatment with these philosphere bacteria in vitro increased Xag-infected soybean germination. Both isolates JB5 and JB7 have the same germination rate of $\pm 95 \%$ with the effectivenes of $\pm 35.71 \%$ compared to control. However, isolate JB13 was the best in increased the length of the radicle by $3.13 \mathrm{~cm}$ with an effectiveness of $104.58 \%$. Isolates JB7, JB12, JB13 and ST32 has the same ability to control soybean pustule disease in vivo with nearly the same disease severity of $21.37 \%$ and effectiveness $\pm 66.41 \%$. Isolates JB12 and $J B 13$ increased the same plant height of $\pm 95.58 \mathrm{~cm}$, the same number of branches \pm 5.53 , the same 
number of leaves of \pm 29.89 . So, isolates JB12, JB13 and ST32, particularly isolates JB5 and JB7 have potential biological agents to control pustule disease and increase soybean growth.

Key word: Phylosphere bacteria, Soybean, Xanthomonas axonopodis pv. glycines

\section{PENDAHULUAN}

Produksi kedelai dalam negeri belum mampu memenuhi kebutuhan sehingga harus mengimpor dari negara lain. Penyakit pustul kedelai yang disebabkan oleh Xanthomonas axonopodispv. glycine (Xag)merupakan kendala dalam budidaya kedelai (Khaeruni dkk, 2007) dan merupakan penyakit penting pada kedelai di Indonesia (Semangun, 1993). Penyakit ini juga merupakan penyakit utama pada kedelai di negara-negara penghasil kedelai (Wrather et al., 2001dalam Zinsou et al, 2015).Penyakit ini menurunkan ukuran dan jumlah biji kedelai dan pada tingkat serangan parah dan kondisi lingkungan mendukung berkisar antara 21-40 \% (Rahayu, 2007.). Karakteristik gejala penyakit pustul bakteri yaitu adanya bercak pada daun berwarna kuning kecoklatan dengan tepi bagian tengah lebih terang (Salerno \& Sagardoy, 2003). Penyebaran patogen ini sebagian besar melalui benih tanaman yang terinfeksi (seedborne pathogen) (Khaeruni dkk, 2007).

Usaha pengendalian penyakit pustul bakteri yang telah dianjurkan antara lain penggunaan varietas tahan (Semangun, 1993), hal tersebut tidak efektif karena Xag mempunyai banyak strain dengan fenotipe dan genotipe yang berbeda-beda (Rukayadi et al.,1999). Penggunaan bakterisida berdampak negatif terhadap lingkungan karena residu yang ditinggalkannya bersifat racun serta terjadinya resistensi bakteri terhadap bakterisida tersebut (Habazar et al., 2010).

PGPB (Pyllosphere Growth Promoting Bacteria) merupakan bakteri yang berada di filosfer dan dapat melindungi tanaman dari pathogen dan memacu pertumbuhan sehingga menyebabkan tanaman menjadi sehat (Lindow \& Brandl, 2003; Wagi \& Amide, 2017; Qin, et al, 2019; Banderez et al, 2020). Pemanfaatan bakteri rizosfer tidak dapat digunakan sebagai agen hayati pathogen filosfer karena tidak bisa establish pada daun (Ilsan et al, 2016). Pemanfaatan bakteri filosfer mempunyai keuntungan untuk penyakit pustule kedelai yang bersifat airborne karena mempunyai kesamaan "niche" dengan pathogen. Hasil penelitian Salerno \& Sagardoy (2003), menunjukkan bahwa Bacillus 210 asal filosfer kedelai berpotensi antagonis terhadap Xag karena dapat menekan perkembangan penyakit pustul bakteri pada kedelai. Menurut Calvalho \& Castillo (2015) bahwa mekanisme mikrooganisme dalam melindungi tanaman dari pathogen dengan mekanisme kompetisi ruang, produksi senyawa antimicrobial, pelepasan metabolit sekunder dan induksi ketahanan. Penelitian bertujuan untuk mengetahui kemampuan 11 isolat bakteri asal filosfer kedelai dalam mengendalikan penyakit pustule bakteri dan memacu pertumbuhan tanaman kedelai.

\section{METODE PENELITIAN}

Penelitian dilaksanakan di Laboratorium Perlindungan Tanaman dan Rumah Kaca Prodi protesi Tanaman Fakultas Pertanian Universitas Jember, pada bulan Agustus hingga Nopember 2018. Bakteri Xag yang digunakan merupakan koleksi Laboratorium Penyakit Tumbuhan Proteksi Tanaman Fakultas Pertanian UNEJ. Bakteri disubkultur pada media YPGA (Yeast Pepton Glucosa Agar) dan diinkubasikan pada suhu ruang selama 48 jam. Kultur murni bakteri diuji patogenesitas pada tanaman kedelai dengan metode Zinsou et al, (2015). Biakan berumur 48 jam sebanyak 2 ose ditumbuhkan pada $100 \mathrm{ml}$ media NB 
(Nutrien Broth) dan dishaker dengan kecepatan 150 rpm selama 48 jam, selanjutnya dibuat kerapatan $10^{8}$ $\mathrm{cfu} / \mathrm{ml}$ dan diinjeksikan pada daun kedelai dan diinkubasikan dengan disungkup 24 jam, selanjutnya diamati gejala yang tampak. Persiapan inokulasi bakteri pada benih maupun tanaman dilakukan dengan dengan cara yang sama.

\section{Persiapan Bakteri PGPB}

Bakteri PGPB (JB4, JB5, JB6, JB7, JB 12, JB13, ST31, ST32, ST4, LB2 dan LB3) merupakan bakteri gram positif asal filosfer kedelai koleksi peneliti yang akan digunakan disubkultur pada media YPGA dan diinkubasikan pada suhu ruang selama 48 jam. Kultur bakteri sebanyak 2 ose ditumbuhkan pada $100 \mathrm{ml}$ media NB dan dishaker dengan kecepatan $150 \mathrm{rpm}$ selama 48 jam, selanjutnya dibuat kerapatan $10^{9} \mathrm{cfu} / \mathrm{ml}$.

\section{Pengujian kemampuan Bakteri Filosfer dalam memacu perkecambahan kedelai}

Penelitian menggunakan Rancangan Acak Lengkap dengan 12 perlakuan dan diulang 3 kali dengan setiap unit percobaan terdiri 20 benih kedelai. Perlakuan tersebut adalah isolat JB 4, JB5, JB6, JB7, JB12, JB1, ST31, ST32, ST4, LB2, LB3 dan control.Benih kedelai varietas Anjasmoro didesinfeksi dengan larutan $0,5 \% \mathrm{NaoCl}$ selama 5 menit dan selanjutnya dibilas tiga kali dengan air steril. Pengujian dibagi dua : 1) tanpa inokulasi Xag dan 2) inokulasi Xag. Pengujian tanpa inokulasi Xag yaitu benih yang telah steril selanjutnya direndam dalam suspensi bakteri filosfer dengan kerapatan $10^{8} \mathrm{cfu} / \mathrm{ml}$ selama 15 menit. Pada perlakuan dengan inokulasi Xag dilakukan dengan cara merendam benih yang telah steril dalam suspensi Xag $10^{8} \mathrm{cfu} / \mathrm{ml}$ selama 15 menit dan setelah ditiriskan kemudian direndam dalam suspensi bakteri dengan kerapatan $10^{8} \mathrm{cfu} / \mathrm{ml}$ selama 15 menit. Benih diletakkan dalam cawan petri yang telah dilapisi dengan kertas saring steril yang lembab. Selanjutnya diinkubasikan selama 4 hari dan diamati daya kecambah dan panjang radikula.

\section{Pengujian kemampuan Bakteri Filosfer dalam mengendalikan penyakit pustul kedelai}

\section{Rancangan Penelitian}

Pengujian dilaksanakan di rumah kaca menggunakan Rancangan Acak Lengkap dengan 12 perlakuan yaitu kontrol, isolat JB 4, JB5, JB6, JB7, JB12, JB1, ST31, ST32, ST4, LB2 dan LB3 yang diulang 3 kali dan setiap unit percobaan terdiri 5 tanaman.

\section{Penanaman kedelai}

Media tanam berupa tanah dan kompos dengan perbandingan 2:1 dicampur secara merata dan dibiarkan selama 1 minggu dan selanjutnya dimasukkan dalam polybag.Benih kedelai varietas Anjasmoro ditanam dengan kedalaman $5 \mathrm{~cm}$ sebanyak 2 benih/polybag. Selanjutnya akan dipilih satu tanaman yang baik. Pemupukan menggunakan urea 0,86 g/tanaman, SP-36 sebanyak 1,66 g/tanaman dan $\mathrm{KCl}$ sebanyak 0,66 gr/tanaman. Pemupukan diberikan sebagai pupuk dasar dan ketika tanaman berumur 3 minggu. Penyiraman dilakukan menyesuaikan kondisi media dan pengendalian OPT dilakukan secara mekanik. 


\section{Inokulasi Bakteri Xag}

Inokulasi patogen dilakukan pada sore hari dengan cara menyemprotkan patogen Xag dengan konsentrasi $10^{8} \mathrm{cfu} / \mathrm{ml}$ pada tanaman kedelai berumur 3 minggu setelah tanam sebanyak $20 \mathrm{ml} /$ tanaman dan disungkup selama 24 jam.

\section{Aplikasi bakteri filosfer}

Aplikasi agen hayati dilakukan pada sore hari dengan cara menyemprotkan bakteri filosfer dengan konsentrasi $10^{9} \mathrm{cfu} / \mathrm{ml}$ pada tanaman kedelai pada 3 hari setelah inokulasi Xag sebanyak 20 $\mathrm{ml} /$ tanaman dan tanaman selanjutnya disungkup selama 24 jam.

\section{Parameter Pengamatan}

Pengamatan dilakukan terhadap masa inkubasi, insidensi penyakit, keparahan dan laju infeksi penyakit. Masa Inkubasi, masa inkubasi dihitung sejak inokulasi Xag hingga adanya gejala penyakit pustule kedelai. Keparahan Penyakit, Pengamatan dilakukan terhadap 6 daun, masing-masing 2 daun bagian bawah, tengah dan atas tanaman. Kriteria penilaian yang digunakan berdasarkan nilai keparahan penyakit dengan nilai skoring $0=$ tidak ada serangan, $1=$ bercak pustul $\leq 5 \%$ dari luas daun, $2=$ bercak pustul antara $5<\mathrm{X} \leq 15 \%$ dari luas daun, $3=$ bercak pustul antara $15<\mathrm{X} \leq 30 \%$ dari luas daun, $4=$ bercak pustul antara $30<\mathrm{X} \leq 50 \%$ dari luas daun $5=$ bercak pustul $>50 \%$ dari luas daun (Khaeruni dkk, 2008). Keparahan Penyakit dihitung dengan rumus Townsend \& Hueberger (1963) dalam Khaeruni dkk, (2008). Keparahan penyakit $=[\Sigma(n i v i) /(\mathrm{NV})] \times 100 \%$, dengan $n i$ : jumlah daun yang terserang pada setiap kategori, $v i$ : nilai numerik masing-masing kategori serangan, $\mathrm{Z}$ : nilai numerik kategori serangan tertinggi (nilai 5) $\mathrm{N}$ : Jumlah daun yang diamati. Laju infeksi penyakit, dihitung dengan rumus van der Plank (1963) yaitu Laju infeksi $(\mathrm{r})=[2.3 /(\mathrm{t} j-\mathrm{t} i)][\operatorname{loge}(\mathrm{x} j / 1-\mathrm{x} j)-\operatorname{loge}(\mathrm{x} i / 1-\mathrm{x} i)$ dengan $\mathrm{t} i$ : waktu pengamatan awal pada hari ke- $i$, $j$ : waktu pengamatan berikut pada hari ke- $j$, $x i$ :keparahan penyakit pada hari ke- $i$, $x j$ : keparahanpenyakit pada hari ke-j.

\section{Analisis data}

Data dianalisis menggunakan software SPSS versi 22 dengan analisis sidik ragam Anova dan jika berbeda nyata dilanjutkan dengan uji DMRT (Duncan Multiple Ring Test) pada taraf 5\%.

\section{HASIL DAN PEMBAHASAN}

\section{Kemampuan PGPB dalam meningkatkan daya perkecambahan kedelai}

Keberadaan bakteri patogen Xag pada benih dapat menurunkan daya kecambah dan panjang radikula perkecambahan benih kedelai. Penggunaan bakteri filosfer untuk seed treatment mampu meningkatkan daya kecambah kedelai serta panjang radikula. 


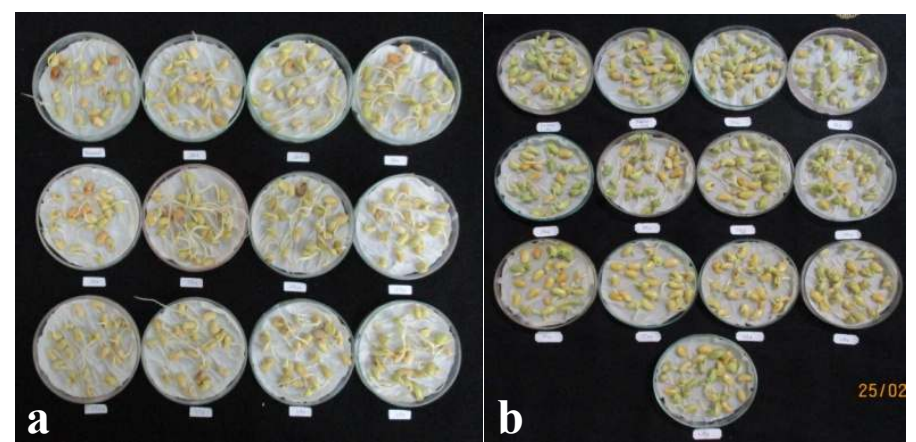

Gambar 1. Daya kecambah kedelai dengan seed treatment menggunakan bakteri PGPB, a) tanpa Xag dan b) inokulasi Xag

Tabel. 1 Kemampuan bakteri filosfer dalam meningkatkan daya perkecambahan kedelai pada 4 hari setelah inokulasi

\begin{tabular}{ccccc}
\hline \multirow{2}{*}{ Perlakuan } & \multicolumn{2}{c}{ Tanpa Xag } & \multicolumn{2}{c}{ Inokulasi Xag } \\
\cline { 2 - 5 } & $\begin{array}{c}\text { Daya kecambah } \\
(\%)\end{array}$ & $\begin{array}{c}\text { efektivitas } \\
(\%)\end{array}$ & $\begin{array}{c}\text { efektivitas } \\
(\%)\end{array}$ \\
\hline JB4 & $91.67 \mathrm{~cd}$ & 17.03 & $88.33 \mathrm{~cd}$ & 26.19 \\
JB5 & $98.33 \mathrm{e}$ & 25.53 & $95.00 \mathrm{c}$ & 35.71 \\
JB6 & $95.00 \mathrm{de}$ & 21.28 & $91.67 \mathrm{~d}$ & 30.96 \\
JB7 & $86.67 \mathrm{~b}$ & 10.65 & $95.00 \mathrm{c}$ & 35.71 \\
JB12 & $100.00 \mathrm{e}$ & 27.67 & $90.00 \mathrm{~cd}$ & 28.57 \\
JB13 & $98.33 \mathrm{e}$ & 25.53 & $85.00 \mathrm{bc}$ & 21.43 \\
ST4 & $91.67 \mathrm{~cd}$ & 17.03 & $91.67 \mathrm{~cd}$ & 30.96 \\
ST31 & $98.33 \mathrm{e}$ & 25.53 & $76.67 \mathrm{ab}$ & 9.53 \\
ST32 & $98.33 \mathrm{e}$ & 25.53 & $88.33 \mathrm{ab}$ & 26.19 \\
LB2 & $88.33 \mathrm{bc}$ & 12.77 & $90.00 \mathrm{~cd}$ & 28.57 \\
LB3 & $98.33 \mathrm{e}$ & 25.53 & $76.67 \mathrm{~cd}$ & 9.53 \\
Kontrol & $78.33 \mathrm{a}$ & - & $70.00 \mathrm{a}$ & - \\
\hline
\end{tabular}

Keterangan : angka yang diikuti huruf yang sama pada kolom yang sama menunjukkan berbeda tidak nyata dalam Uji DMRT pada taraf kepercayaan 5\%.

Kesebelas bakteri filosfer mempunyai kemampuan untuk meningkatkan daya perkecambahan kedelai pada perlakuan tanpa Xag maupun pada perlakuan inokulasi Xag, beberapa isolate menunjukkan kemampuan yang sama (Gambar 1 dan Tabel 1). Inokulasi Xag pada benih menyebabkan penurunan daya kecambah benih kedelai.Seed treatment tanpa pathogen Xag menunjukkan daya kecambah berkisar 86,67 hingga $100 \%$, sementara kontrol hanya 78,33\%. Isolat JB12 menunjukkan efektivitas paling tinggi sebesar 27,67\%. Pada seed treatment dengan inokulasi Xag menunjukkan daya kecambah dengan kisaran $76,67 \%$ hingga 95\% dibandingkan control 70\%. JB7 merupakan isolate terbaik dalam meningkatkan daya kecambah dengan efektivitas $35,71 \%$. 


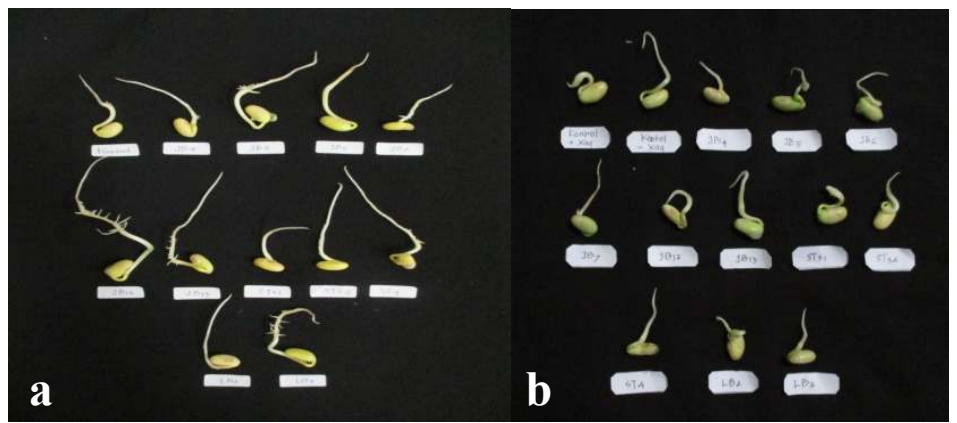

Gambar 2. Panjang radikula kecambah kedelai dengan seed treatment menggunakan bakteri PGPB, a) tanpa Xag dan b) inokulasi Xag

Tabel 2. Kemampuan Bakteri Filosfer dalam meningkatkan panjang radikula kecambah kedelai pada 4 hari setelah inokulasi

\begin{tabular}{ccccc}
\hline \multirow{2}{*}{ Perlakuan } & \multicolumn{2}{c}{ Tanpa Xag } & \multicolumn{2}{c}{ Inokulasi Xag } \\
\cline { 2 - 5 } & Panjang radikula & Efektivitas & Panjang Radikula & $\begin{array}{c}\text { Efektivitas } \\
(\mathrm{cm})\end{array}$ \\
\hline JB4 & $4.47 \mathrm{c}$ & 73.93 & $1.53 \mathrm{a}$ & $(\%)$ \\
JB5 & $4.53 \mathrm{c}$ & 76.26 & $2.20 \mathrm{~b}$ & 0 \\
JB6 & $4.50 \mathrm{c}$ & 75.1 & $2.47 \mathrm{c}$ & 43.79 \\
JB7 & $4.57 \mathrm{c}$ & 77.82 & $2.53 \mathrm{c}$ & 61.44 \\
JB12 & $7.93 \mathrm{f}$ & 208.56 & $1.53 \mathrm{a}$ & 65.36 \\
JB13 & $7.70 \mathrm{e}$ & 199.61 & $3.13 \mathrm{~d}$ & 0 \\
ST4 & $4.10 \mathrm{~b}$ & 59.53 & $2.20 \mathrm{~b}$ & 104.58 \\
ST31 & $4.47 \mathrm{c}$ & 73.93 & $1.67 \mathrm{a}$ & 43.79 \\
ST32 & $5.07 \mathrm{~d}$ & 97.28 & $2.37 \mathrm{bc}$ & 9.15 \\
LB2 & $4.43 \mathrm{e}$ & 72.37 & $1.57 \mathrm{a}$ & 54.9 \\
LB3 & $4.40 \mathrm{e}$ & 71.21 & $2.37 \mathrm{bc}$ & 2.61 \\
Kontrol & $2.57 \mathrm{a}$ & - & $1.53 \mathrm{a}$ & 54.9 \\
\hline
\end{tabular}

Keterangan : angka yang diikuti huruf yang sama pada kolom yang sama menunjukkan berbeda tidak nyata dalam Uji DMRT pada taraf kepercayaan 5\%.

Seed treatment dengan bakteri filosfer mampu meningkatkan panjang radikula (Gambar 2 dan Tabel 2). Inokulasi Xag menurunkan panjang radikula, namun semua isolate masih mampu meningkatkan panjang radikula dibandingkan control kecuali isolate JB4 dan JB 12. Perlakuan benih tanpa inokulasi Xag menunjukkan panjang radikula berkisar $4.40 \mathrm{~cm}$ hingga $7.93 \%$, isolate JB 12 mempunyai kemampuan paling baik dengan efektivitas 208,56\%. Pada benih yang diinokulasi dengan Xag menunjukkan panjang radikula berkisar $1,53 \mathrm{~cm}$ hingga $3,13 \mathrm{~cm}$, isolate JB13 mempunyai efektivitas terbesar $104.58 \%$.

Bakteri filosfer mampu meningkatkan daya kecambah dan pemanjangan radikula diduga karena bakteri tersebut mampu menghasilkan hormone pertumbuhan seperti IAA, sitokinin dan etilen (Chaudary et al. 2016). Hormon IAA ini ini berperan dalam pembelahan sel, pemanjangan sel, fitotaktic movement dan deferensiasi jaringan, selain itu bakteri filosfer juga memfiksasi nitrogen, melarutkan posfat, dan 
menghasilhan hydrogen cyanide (Batool et al 2016). Bakteri filosfer mampu meningkatkan daya kecambah dan panjang radikula benih kedelai yang diinokulasi pathogen Xag karena bakteri filosfer tersebut mempunyai daya antagonistik terhadap Xag (data tidak dipublikasikan). Hal ini seperti hasil penelitian Salerno \& Sagardoi (2003) bahwa Bacillus sp 210 asal filosfer yang mempunyai daya antagonistic secara in vitro mampu mengurangi jumlah bercak akibat Xag pada daun kedelai. Beberapa isolate tersebut tidak mampu memperpanjang radikula dengan adanya infeksi Xag pada benih.

\section{Kemampuan Bakteri Filosfer dalam Mengendalikan penyakit pustul kedelai}

Gejala penyakit pustul kedelai tampak terlebih dahulu dimulai dari daun-daun tua yang ditunjukkan dengan adanya bercak berwarna kuning pada permukaan daun dan selanjutnya akan berkembang membentuk bintik kecil dan menjadi pustul berwarna coklat muda dan menjadi coklat tua yang dikelilingi halo kuning (Gambar 3). Hal tersebut seperti yang didiskripsikan oleh Prathuangwong \& Choethana (1998), dan Salerno\& Sagardoy (2003).

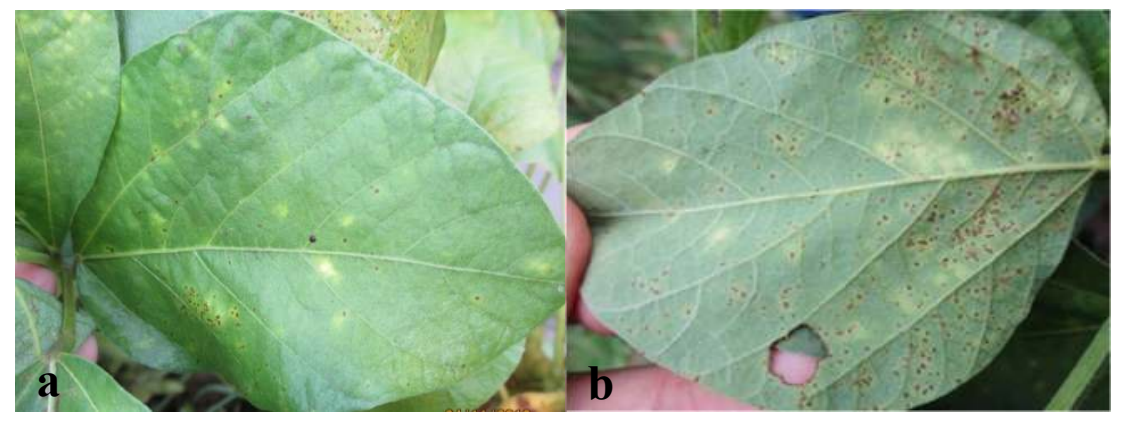

Gambar 3. Gejala penyakit pustule bakteri pada daun a) permukaan atas daun, b) permukaan bawah daun

Aplikasi bakteri filosfer tidak mampu memperpanjang masa inkubasi penyakit namun mempunyai kemampuan dalam mengendalikan penyakit pustul kedelai dengan menghambat laju infeksi dan menunjukkan efektivitas yang beragam (Gambar 4 dan Tabel 3). Masa inkubasi penyakit berkisar antara 8-13 hari setelah inokulasi. Aplikasi bakteri filosfer 3 hari setelah inokulasi Xag tidak mampu menghambat infeksi patogen tersebut sehingga masa inkubasi sama dengan kontrol tanpa bakteri filosfer. Bakteri berkembang dalam ruang antar sel dan menyebar sehingga menimbulkan gejala pustul yang semakin banyak seiring dengan semakin tambahnya umur tanaman dan menyebar pada daun - daun lain. Selain karena inokulasi buatan, diduga ada kemungkinan ada bakteri yang terbawa benih sehingga gejala lebih cepat tampak. Bakteri filosfer mampu menghambat laju infeksi patogen sehingga keparahan penyakit dapat dikendalikan. 


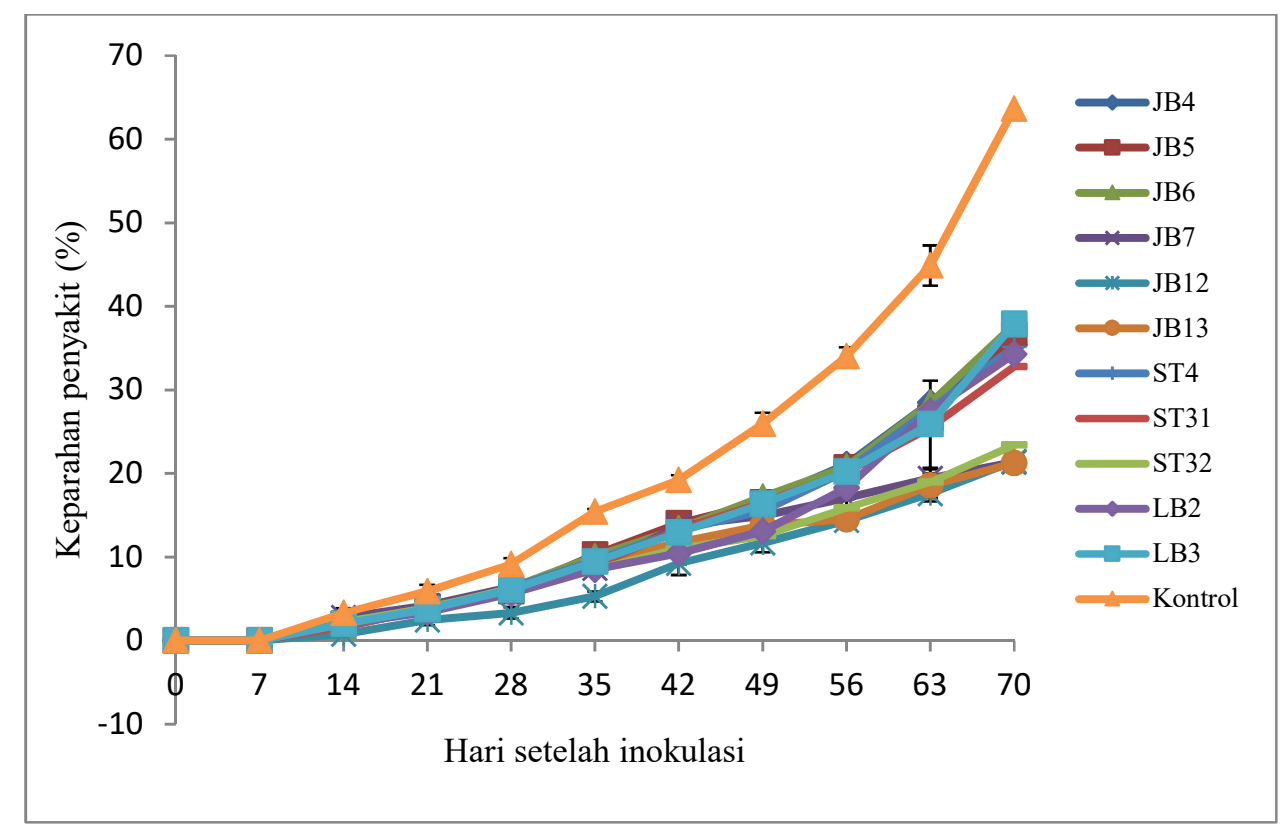

Gambar 3. Perkembangan penyakit pustul kedelai dengan aplikasi bakteri filosfer

Tabel 3. Kemampuan bakteri filosfer dalam mengendalikan penyakit pustul kedelai

\begin{tabular}{ccccc}
\hline Perlakuan & $\begin{array}{c}\text { Masa inkubasi } \\
\text { (hari) }\end{array}$ & $\begin{array}{c}\text { Keparahan penyakit } \\
70(\%)\end{array}$ & $\begin{array}{c}\text { Laju infeksi } \\
\text { unit/hari }\end{array}$ & $\begin{array}{c}\text { Efektivitas } \\
(\%)\end{array}$ \\
\hline JB4 & $9-12$ & $35.48 \mathrm{bc}$ & 0.049 & 44.24 \\
JB5 & $9-11$ & $36.66 \mathrm{bc}$ & 0.050 & 42.38 \\
JB6 & $9-12$ & $37.82 \mathrm{~b}$ & 0.053 & 40.57 \\
JB7 & $9-11$ & $21.37 \mathrm{~d}$ & 0.034 & 66.41 \\
JB12 & $8-12$ & $21.47 \mathrm{~d}$ & 0.035 & 66.25 \\
JB13 & $9-12$ & $21.25 \mathrm{~d}$ & 0.033 & 66.60 \\
ST4 & $9-11$ & $35.14 \mathrm{bc}$ & 0.047 & 44.77 \\
ST31 & $10-11$ & $32.80 \mathrm{c}$ & 0.044 & 48.46 \\
ST32 & $10-12$ & $23.41 \mathrm{~d}$ & 0.039 & 63.21 \\
LB2 & $9-13$ & $34.29 \mathrm{bc}$ & 0.048 & 46.11 \\
LB3 & $8-11$ & $37.92 \mathrm{~b}$ & 0.050 & 40.40 \\
Kontrol & $9-12$ & $63.63 \mathrm{a}$ & 0.082 & - \\
\hline
\end{tabular}

Keterangan : angka yang diikuti huruf yang sama pada kolom yang sama menunjukkan berbeda tidak nyata dalam Uji DMRT pada taraf kepercayaan $5 \%$.

Keparahan penyakit pada 70 hsi menunjukkan bahwa isolat JB7, JB12, JB13 dan ST32 merupakan isolat terbaik dengan kemampuan yang sama dalam mengendalikan penyakit dengan nilai keparahan penyakit masing-masing $21,37 \% ; 21,47 \%$ dan $21,25 \%$. Sedangkan isolat yang lain mempunyai kemampuan yang lebih rendah dan juga mempunyai kemampuan yang sama. Keempat isolat terbaik tersebut menunjukkan efektifitas yang tinggi dalam mengendalikan penyakit pustul berkisar $63,21 \%$ $66,60 \%$, sedangkan isolat yang lain berkisar $40,40 \%-48,46 \%$. 
Kemampuan bakteri filosfer dalam mengendalikan penyakit ini juga sama dengan hasil penelitian Ilsan et al,(2016) bahwa empat bakteri filosfer mampu mengendalikan penyakit hawar daun bakteri pada padi dan isolat STG15 merupakan isolat terbaik dapat menekan keparahan penyakit sebesar 28,87 \% pada 14 hsi. Hasil penelitian Megasari dkk (2017) menunjukkan bahwa Bacillus dan Corynebacterium mampu mengendalikan penyakit pustule kedelai dengan intensitas penyakit $0 \%$ sementara control $25 \%$.

Salah satu mekanisme bakteri filosfer tersebut dalam mengendalikan penyakit pustul karena terkait dengan kemampuannya dalam menghasilkan senyawa antibakteri yang bersifat bakteriostatik dan kecepatan tumbuh koloninya (data tidak dipublikasikan). Produksi senyawa antibakteri oleh bakteri filosfer akan menghambat pertumbuhan patogen (Salerno \& Sagardoi, 2003; Nurfitriani $d k k$, 2016). Kecepatan tumbuh berhubungan dengan kemampuannya dalam kompetisi ruang dan nutrisi. Selain hal tersebut diduga terjadi induksi ketahanan tanaman. Induksi ketahanan terjadi dengan memperkuat dinding sel tanaman dan meningkatkan sintesis bahan kimia (Compant et al., (2005), sintesis PR protein (Schmoock et al, 2008).Aplikasi agen hayati Bacillus pada daun kedelai menyebabkan daun terkolonisasi oleh Bacillus sehingga penyakit pustul bakteri menjadi tertekan (Salareno \& Sagardoy, 2003).Kemampuan bakteri filosfer tersebut sangat didukung oleh kondisi lingkungan, saat dilakukan penelitian pada saat memasuki musim hujan dengan cuaca yang lembab dan hangat sehingga bakteri dapat berkembang dengan baik.Aplikasi bakteri filosfer dapat digunakan sebagai salah satu agens pengendali hayati penyakit pustule kedelai.

\section{Kemampuan PGPB dalam meningkatkan pertumbuhan kedelai}

Beberapa bakteri filosfer mampu meningkatkan tinggi tanaman, jumlah cabang dan jumlah daun secara nyata (Tabel 3). Isolat JB12, JB13 dan ST32 terbaik dalam meningkatkan tinggi tanaman dengan kemampuan yang sama secara berurutan $96,69 \mathrm{~cm}, 96,07 \mathrm{~cm}$ dan 95,38 cm. Sedangkan JB7, JB 12 dan JB 13 merupakan isolate terbaik dalam meningkatkan jumlah cabang sejumlah 5 cabang. Isolat JB7, JB12, JB13, ST31 dan ST32 menunjukkan kemampuan yang tinggi dalam meningkatkan jumlah daun berkisar 23,75 - 25,01 daun. Isolat-isolat lain mempunyai kemampuan yang lebih rendah bahkan ada yang tidak memberikan pengaruh terhadap pertumbuhan tanaman.

Tabel 4. Pertumbuhan kedelai dengan aplikasi bakteri filosfer

\begin{tabular}{cccc}
\hline \multirow{2}{*}{ Perlakuan } & \multicolumn{3}{c}{ Pertumbuhan kedelai $(70 \mathrm{hst})$} \\
\cline { 2 - 4 } & Tinggi & Jumlah cabang & Jumlah daun \\
\hline JB4 & $91.10 \mathrm{~d}$ & $4.40 \mathrm{c}$ & $21.96 \mathrm{bc}$ \\
JB5 & $92.37 \mathrm{~cd}$ & $4.37 \mathrm{c}$ & $21.49 \mathrm{bc}$ \\
JB6 & $89.13 \mathrm{ef}$ & $4.23 \mathrm{c}$ & $20.97 \mathrm{c}$ \\
JB7 & $93.77 \mathrm{bc}$ & $5.06 \mathrm{ab}$ & $23.75 \mathrm{ab}$ \\
JB12 & $96.69 \mathrm{a}$ & $5.48 \mathrm{a}$ & $25.01 \mathrm{a}$ \\
JB13 & $96.07 \mathrm{a}$ & $5.58 \mathrm{a}$ & $24.89 \mathrm{a}$ \\
ST4 & $91.25 \mathrm{~d}$ & $4.47 \mathrm{c}$ & $21.25 \mathrm{c}$ \\
ST31 & $90.69 \mathrm{e}$ & $4.25 \mathrm{c}$ & $21.76 \mathrm{bc}$ \\
ST32 & $95.38 \mathrm{ab}$ & $4.24 \mathrm{c}$ & $24.40 \mathrm{a}$ \\
LB2 & $92.10 \mathrm{~cd}$ & $4.67 \mathrm{bc}$ & $21.58 \mathrm{bc}$ \\
LB3 & $91.03 \mathrm{~d}$ & $4.37 \mathrm{c}$ & $20.58 \mathrm{c}$ \\
Kontrol & $88.77 \mathrm{f}$ & $4.18 \mathrm{c}$ & $19.78 \mathrm{c}$ \\
\hline
\end{tabular}

Keterangan : angka yang diikuti huruf yang sama pada kolom yang sama menunjukkan berbeda tidak nyata dalam Uji DMRT pada taraf kepercayaan 5\%. 
Isolat-isolat yang mempunyai kemampuan dalam meningkatkan pertumbuhan tanaman diduga disebabkan oleh kemampuannya dalam menghasilkan fitohormon yang dapat memacu pertumbuhan tanaman. Bakteri filosfer mampu menghasilkan IAA, nitrat reduktase, ekskresi NH3 dan melarutkan posfat (Kumar et al, 2018). Bakteri endofitik filosfer mampu menghasilkan IAA yang dapat memacu pertumbuhan tanaman dengan meningkatkan panjang akar dan batang, biomassa basah dan kering serta kandungan klorofil (Shahdad et al, 2017).Boiero et al. (2007) menguji tiga strain Bradyrhizobium japonicum secara in vitro menghasilkan senyawa auxins, cytokinins, gibberellic acid (GA3), abscisic acid (ABA) and ethylene dengan kemampuan yang berbeda dan itu mempengaruhi kemampuannya dalam memacu pertumbuhan tanaman. Genus bakteri Bacillus, Pseudomonas, Escherichia, Micrococcus and Staphylococcus yang berasosiasi dengan tanaman herba untuk meningkatkan hormone IAA indigenousdan pertumbuhan Triticum aestivum var. Inqalab-91.M (Ali et al, 2008).

Hasil penelitian secara keseluruhan menunjukkan bahwa beberapa isolat bakteri filosfer tersebut tidak konsisten dalam menekan perkembangan penyakit serta memacu pertumbuhan kedelai pada pengujian seed treatment dan aplikasi pada tanaman.Hal tersebut diduga terkait dengan kemampuan bakteri beradaptasi pada lingkungan filosfer yang penuh dengan cekaman suhu, radiasi, kelembaban, permukaan daun, nutrisi, fisiologi dan umur tanaman.Hal ini seperti penelitian Braunet al (2010) menunjukkan bahwa toksin yang dihasilkan oleh bakteri Pss22d mampu menghambat Psg secara in vitro tetapi tidak berpengaruh ketika diaplikasikan pada tanaman.

Beberapa bakteri filosfer yang diuji tersebut mempunyai kemampuan dalam memacu pertumbuhan tanaman dan mengendalikan pustul kedelai sehingga dapat menyebabkan tanaman lebih sehat (Kumar, et al. 2018; Bendarez et al, 2020).

\section{KESIMPULAN}

Isolat JB7, JB12, JB13 dan ST32 menunjukkan potensi yang baik dalam mengendalikan penyakit pustule kedelai dan meningkatkan pertumbuhan tanaman kedelai sehingga perlu diteliti lebih lanjut pada uji di lapangan, pengujian mekanisme sebagai bioprotektan, biostimulan dan biofertilizer serta formulasinya.

\section{UCAPAN TERIMA KASIH}

Penelitian ini didanai oleh Hibah Mendukung IsDB Universitas Jember dengan SK Rektor UNEJ No: 12509 / UN25 / LT / 2018 dan no kontrak : 4077 / UN25.3.1 / LT.1 / 2018

\section{DAFTAR PUSTAKA}

Ali, B., Sabri, A.N, Ljung, K dan Hasnain, S., 2009, Auxin Production by Plant Associated Bacteria: Impact on endogenous IAA content and Growth of Triticum aestivum L, Letters in Applied $\begin{array}{llllll}\text { Microbiology. } & 48 & \text { (5). } & 542 & - & 547 \text {, }\end{array}$ https://sfamjournals.onlinelibrary.wiley.com/doi/full/10.1111/j.1472-765X.2009.02565.x

Baldares-Ruiz K.A, Bustos, P, Rosa, I., Santamaria, Gonzales,V., Fajardo, S.Ac Ortiz, S.B., M. Villalobos, M., Ocampo, S.A., Garcia, A.A.G., Galindo, E., dan Gareon, L.S., 2020, Bacillus velezensis 83 a Bacterial strain from Mango Phy;oshere, useful for Biological Control \& Plant Growth Promotion, AMB Exp, 10.163, https://doi.org/10.1186/s13568-020-01101-8 
Batool F., Rehman, Y., dan Hasnain, S., 2016, Phylloplane Associated Plant Bcteria of Commercially Superior Wheat Varieties Exhibit Superior Plant Growth Promoting Abilities. Frontiers in Life Science, $\quad$ No $\quad 9, \quad$ Vol $\quad 4,313-322$. https://www.researchgate.net/publication/311341194_Phylloplane_associated_plant_bacteria of commercially_superior_wheat_varieties_exhibit_superior_plant_growth_promoting_abilities

Boiero, L., Perrig, Masciarelli, D., Penna, O., Cassan, C., dan Luna, V., 2007, Phytohormone production by three strains of Bradyrhizobium japonicum and possible physiological and technological implications, Appl Microbiol Biotechnol, No 74, Vo. 4, 874-880. https://pubmed.ncbi.nlm.nih.gov/17136369/

Braun S.D., Hofmann, Wensing, J., Weingart, A., Ullrich, dan Spiteller D., 2010, In vitro antibiosis by Pseudomonas syringae Pss22d, acting against the bacterial blight pathogen of soybean plants, does not influence in planta biocontrol. J. Phytopathol, No 158, 288-295. https://onlinelibrary.wiley.com/doi/abs/10.1111/j.1439-0434.2009.01612.x

Carvalho, D.S dan Castillo, A., 2015, Influence of light on Plant - phyllosphere interaction. (review). $\begin{array}{llllll}\text { Frontiers in plant } & \text { science. }\end{array}$ https://www.frontiersin.org/articles/10.3389/fpls.2018.01482/full

Chaudhary, D., Kumar, R., Sihag, K., Rashmi dan Kumari , A., 2017, Philospheric microflora and its impact on plant growth: A review. Agricultural Reviews, No 38, Vol 1, 5159.https://www.semanticscholar.org/paper/Phyllospheric-microflora-and-its-impact-on-plant-AChaudhary-Kumar/299c4e2cc7ebb9e5342abd9ee95129de3d452b4a

Compant, S., Duffy, B., Nowak, J., Clement, C., and Barka, E. A., 2005, Use of Plant Growth-Promoting Bacteria for Biocontrol of Plant Diseases: Principles, Mechanisms of Action, and Future Prospects. Applied and Environmental Microbiology, No. 9, Vol. 71, 49514959.https://aem.asm.org/content/71/9/4951

Habazar, T, Resti, Z., Yanti, Y., Sutoyo, Imelda, 2015, Formulasi Bakteri Endofit Akar Kedelai untuk Pengendalian Pustul Bakteri, JFI, No 2, Vol. 11, 51-58.

Ilsan N.A.,A.A Nawangsih \& A.T Wahyudi. 2016. Rice Phyllosphere Actinomycetes as Biocontrol Agent of Bacterial Leaf Blight Disease on Rice. Asian Journal of Plant Pathology. DOI: 10.39923/ajppaj.2016.1.8.https://www.researchgate.net/publication/307467819 Rice Phyllosphe re Actinomycetes as Biocontrol Agent of Bacterial Leaf Blight Disease on Rice

Khaeruni, A. R., Tjahjono, B., Suwanto, A. dan Sinaga, M. S. 2008. Virulensi Sejumlah Isolat Xanthomonas sxonopodis pv glyciness Asal Edamame pada Tiga Varietas Kedelai. HPT Tropika, No.1, Vol. 8, 39-40.http://jhpttropika.fp.unila.ac.id/index.php/jhpttropika/article/view/262

Khaeruni.A., Suwanto,A.,Tjahjono, B., dan Sinaga, M.S., 2007, Short Communication. Deteksi Cepat Penyakit Pustul Bakteri pada Kedelai Menggunakan Teknik PCR dengan Primer Spesifik, J. Hayati, No 14, Vol. 2: 76-80, https://core.ac.uk/download/pdf/82034357.pdf

Kumar S., Caudhary, D., Rashmi, Jangra, dan Kumar, R., 2018, Exploring Phyllosphere Bacteria for Growth Promotion dan Yield of Potato (Solanum tuberosum L.), Int.J.Curr.Microbiol.App.Sci, No 7, Vol. 4, 1065-1071. https://www.ijcmas.com/7-4-2018/Satish\%20Kumar2,\%20et\%20al.pdf 
Lindow, S. E. dan Brandl, M.T., 2003, Microbiology of the Phyllosphere. Applied and Enviromental Microbiology, No. 4, Vol. 69, 1875-1883.https://pubmed.ncbi.nlm.nih.gov/12180099/

Megasari, A., Abadi, A.L., dan Aini.,L.Q, 2017, Potensi Corynebacterium sp dan Bacillus sp. Untuk Mengendalikan Penyakit Pustul Bakteri pada Tanaman Kedelai, Jurnal HPT, No 5, Vol.1, 23-29. http://jurnalhpt.ub.ac.id/index.php/jhpt/article/view/251

Nurfitriani, R., Krishanti, N. P. R. A., Akhdiya, A., dan Wahyudi, A.T., 2016,Penapisan Bakteri Filosfer Penghasil Senyawa Bioaktif Anti Xanthomonas oryzae pv. oryzae Penyebab Penyakit Hawar Daun pada Padi, Jurnal Sumberdaya Hayati, No 2, Vol.1, 1924.file://C:/Users/ASUS/Downloads/15387-Article\%20Text-45785-1-10-20170228.pdf

Qin C., Tao, J., Liu, T., Xiao, N., Li, T., Gu, Y., Yin, H., dan Meng, D., 2019, Reponses of Phyllosphere microbiota and Plant Healt to Application of Two Different Biocontrol Agents, AMB Express, 9:2. https://doi.org/10.1186/s13568-019-0765-x

Rahayu, M, 2016, Patologi dan Teknis Pengujian Kesehatan Benih Tanaman Aneka Kacang. Buletin Palawija, No14, Vol.2,78-88. http://ejurnal.litbang.pertanian.go.id/index.php/bulpa/article/view/9175/0

Rukayadi, Y., B. Tjahjono, dan Suwanto, A., 2000. Survival and Epiphytic Fitness of a Nonpathogenic Mutant of Xanthomonas campestris pv. glycines. Applied and Environmental Microbiology, No. 3, Vol. 66, 1183-1189.https://www.ncbi.nlm.nih.gov/pmc/articles/PMC91960/

Salerno, C.M., dan Sagardoy, M.A., 2003, Short comunication: Antagonistic activity Bacillus subtilis againt Xanthomonas campestrispv. glycines under controlled condition. Spanish Journal of Agriculture Research, No1, 55-58. https://pdfs.semanticscholar.org/3efe/38f3e9339e856186c485a0a874836026aac3.pdf

Schmoock, S. Kürkcüoglu, S. dan Gau, A. E.,2008, Biological control of apple scab and fire blight by the application of the non-pathogenic bacterium Pseudomonas fluorescens Bk3 to the leaf surface. In: Boos, Markus (Ed.) Ecofruit - 13th International Conference on Cultivation Technique and Phytopathological Problems in Organic Fruit-Growing: Proceedings to the Conference from 18thFebruary to 20th February 2008 at Weinsberg/Germany, pp. 306-309. https://orgprints.org/13736/

Semangun, H., 1993, Penyakit-Penyakit Tanaman Pangan di Indonesia, Gadjah Mada University Press, Yogyakarta.

Shahzad S., Waqas, M., Khan, A.A., Al Hosni,K., Kang,S.M., Seo, C.W., dan Lee, I.J., 2017. Indole Acetic Acid Production and Plant Growth Promoting Potential of Bacterial endophyties Isolated From Rice (Oryza sativa L.) Seed.Acta Biologica Hungarica, N.68 , Vol. 68, 175-186. https://pubmed.ncbi.nlm.nih.gov/28605980/

Van der Plank, J. E., 1963, Plant Disease: Epidemics and Control. Academic Press, New York.https://www.amazon.com/Plant-Diseases-Epidemics-Van-Plank/dp/B0006AYRUI

Wagi, S dan A. Ahmed, A., 2017, Phyllospheric Plant Growth Promoting Bacteria, Journal of Bacteriology and Mycology: open access, Issu 1, Vol.5, 215-216. 
Agritrop, Vol. 18 (2): 124 - 136

DOI: 10.15406/jbmoa.2017.05.00119, https://medcraveonline.com/JBMOA/phyllospheric-plantgrowth-promoting-bacteria.html

Zinsou, V. A., Afouda, L. A. C., Zoumarou-Walls, N., Pate-Bata, T., Dossou, L., dan Gotz, M., 2015, Occurrence and Characterisation of Xanthomonas axonopodis pv. glyciness, Causing Bacterial Pustules on Soybean In Guinea Savanna of Benin. African Crop Science Journal, No. 3, Vol. 23, 203 - 210.https://www.ajol.info/index.php/acsj/issue/view/12673 